\title{
Internationalization and Performance of Emerging Market Firms: Institutional Embeddedness in Advanced Economies
}

\author{
Hamid Akbari \\ Ph.D. awarded by York University, Schulich School of Business, June 2012
}

THE WORLD IS FASCINATED with emerging market (EM) firms that are starting to establish a global presence. These are firms that have been able to survive and grow despite various "institutional voids" (Khanna \& Palepu, 1997) in their home countries and have managed to attract the capital and talent necessary to start internationalizing. Nevertheless, they often lag behind global competitors in brand names, innovation processes, technology, and management systems. Many of these EM firms are searching for ways to catch up by making acquisitions in advanced economies (Madhok \& Keyhani, 2012).

My research suggests that tapping into the benefits of superior institutional environments (Chan, Isobe, \& Makino, 2008) may be a primary driver of international acquisitions, and that an EM firm's capacity to absorb learning from the more complex and developed institutional environment determines the performance outcomes. The results of this study indicate that EM firms that become embedded in advanced economies experience negative performance effects in the short run but realize positive performance outcomes in the long run. Contrary to the intuitively-appealing prediction of the theory of incremental internationalization (Johanson \& Vahlne, 1977), the results suggest that EM firms realize greater performance benefits when they expand to more institutionally-distant advanced economies.

\section{Which country is an emerging economy?}

Given that the literature does not offer a clear-cut list of emerging and advanced economies (Hoskisson, Eden, Lau, \& Wright, 2000), I studied 59 countries that had enough impact on the global economy to be listed in the World Competitiveness Yearbooks and to be covered by international organizations such as the World Bank. I started with categorizing countries into emerging and advanced using: (a) the International Monetary Fund's list of advanced and emerging economies; (b) the Human Development Index; and (c) the GDP Growth. This analysis identified 24 advanced economies (such as France, Japan, New Zealand, and the USA) which consistently met all three criteria in the past 15 years. There are, however, a number of countries with mixed results. For example, South Korea and Singapore are listed as advanced economies in the IMF and are ranked very high on their $\mathrm{HDI}$, but have experienced the rapid growth of typical emerging economies. I have identified this distinct group as countries in transition from emerging to advanced-economy status (Czech Republic, Estonia, Ireland, South Korea, Singapore, Slovak Republic, Slovenia, and Taiwan). Finally, 27 emerging economies (such as Brazil, China, India, Mexico, Poland, Russia, South Africa, and Turkey) were identified.

For these 27 emerging economies, I developed a dataset of public firms and then tracked each firm's past acquisitions using the SDC Platinum database provided by Thomson Reuters. These past acquisitions dated back to 1977 and included all domestic and international acquisitions. The final dataset was comprised of 9,699 distinct firms (in 78 different industry groups) that had a total of 71,522 acquisitions.

\section{What type of acquisitions can create more value for EM firms?}

I found that EM firms that have made acquisitions in advanced economies experience higher firm performance (measured by return on total assets) vis-à-vis other EM firms (with no prior acquisition or with other types of acquisitions). To be able to compare the performance impact of international acquisitions in advanced economies with acquisitions in countries that ranked lower on the level of institutional development, each EM firm's past acquisitions were categorized into four groups: acquisitions in advanced economies, acquisitions in transitional economies, acquisitions in emerging economies, and domestic acquisitions. My analysis indicated that there was no significant relationship between firm performance and international acquisitions in transitional or other emerging economies. Similarly, there was no significant relationship between firm performance and past domestic acquisitions. There was, however, a significant positive relationship between firm performance and past acquisitions in advanced economies. Therefore, on average, EM firms with past acquisitions in advanced economies have a higher performance than other EM firms.

\section{How does post-acquisition performance change over time?}

One would argue that the stronger performance of EM firms with acquisitions in advanced economies might be attributable to their pre-acqui- 
sition strength, rather than post-acquisition performance enhancement. Hence, I conducted longitudinal analyses to understand how an EM firm's performance changed over time after an acquisition had been completed.

Findings revealed that EM firms' acquisitions in advanced economies were associated with negative performance effects in the short term. This is likely due to overpayment for the acquisition, the liability of foreignness (Zaheer, 1995), the liability of newness in advanced economies (Madhok \& Keyhani, 2012), and the gradual and incremental nature of learning required for a distant institutional environment. However, the expansion of EM firms into advanced economies led to positive financial outcomes in the long term.

\section{How does institutional gap affect performance outcomes?}

I define an institutional gap as the positive or negative difference in the level of institutional development between the domestic (home) country and the foreign (host) country to which a firm expands. The institutional gap for internationalization from emerging economies to advanced economies is by and large positive, as advanced economies often enjoy a greater level of institutional development vis-à-vis emerging economies. To measure the level of institutional development within each country, 14 indicators were obtained from the World Competitiveness Yearbooks and used as proxies for the economic, political, and social institutions. Included in these 14 items are the Distribution Infrastructure, Financial Resources, the Educational System, Innovative Capacity, Intellectual Property, the Regulatory Framework, Corruption, and the Ease of Doing Business. sidered the direction of institutional distance (Zaheer, Schomaker, \& Nachum, 2012); the results from this study show that distance is not direction-neutral and, in fact, the direction of international acquisitions matters greatly. For example, a Brazilian firm operating in the United States faces institutional obstacles that are different from those faced by an American firm operating in Brazil. Indeed, this research suggests that a positive institutional gap is beneficial for performance over the long term.

As incremental internationalization theory implies, a wide institutional gap may lead to a large liability of foreignness and poor performance outcomes in the short run. In the long run, however, a wider institutional gap may be a substantial source of learning and value creation, leading to capability development and ultimately greater performance benefits from international expansion. Thus, it is important to distinguish between short term and long term performance outcomes of internationalization because after entry to a foreign market, the negative impact due to the liability of foreignness may attenuate over time, whereas learning benefits may increase.

My analysis suggests that it may take EM firms as long as 18 years to realize a positive performance for their acquisitions in advanced economies. In this particular form of acquisition, the challenges can extend beyond the internal processes of post-acquisition integration and implementation to learning how to navigate and operate in a very complex, different institutional environment.

The results of this study also indicated that a greater level of unabsorbed slack resources (Tan \& Peng, 2003), for example lower debt-to-equity ratio, improved the performance outcomes of internationalization. EM firms with a higher absorptive capacity (measured by R\&D intensity)

I found that a greater positive institutional gap in acquisitions is associated with better performance outcomes. EM firms that expand to advanced economies with significantly higher levels of institutional development gain access to knowledge, resources, and capabilities that are not available to them in their domestic environment. The cost of such expansion to institutionally distant countries is very high, as theories of internationalization correctly predict. But this distant expansion allows EM firms to learn new and diverse capabilities practiced in advanced economies, transfer them back home, and defend their domestic business against the presence of global leading firms that entered their liberalized, deregulated domestic markets. Hence, even the costly expansion of EM firms to very different advanced institutional environments can be associated with higher performance for the corporation and it is the performance of the corporation, rather than the subsidiary in the advanced economy, that should be optimized.

\section{Concluding Remarks}

This study contributes to our understanding of "institutional distance" (Kostova, 1999, Xu \& Shenkar, 2002). Previous research had not fully con-

gained more from expansion into advanced economies. Furthermore, expansion into related industries at a lower expansion pace was associated with greater benefits. Taken together, this research suggests that expanding into advanced economies can help EM firms to build capabilities, but learning to navigate in advanced economies is a slow process and EM firms will need unabsorbed slack resources to leverage capability development. Further, a wider institutional gap between the emerging economy (home) and the advanced economy (host) may lead to better performance results, underscoring potential benefits of accessing an advanced economy institutional environment for EM firms. 


\section{References}

Chan, C. M., Isobe, T., \& Makino, S. 2008. Which country matters? Institutional development and foreign affiliate performance. Strategic Management Journal, 29: 1179-205.

Hoskisson, R. E., Eden, L., Lau, C. M., \&Wright, M. 2000. Strategy in emerging economies. The Academy of Management Journal, 43(3): 24967.

Johanson, J. \& Vahlne, J. E. 1977. The internationalization process of the firm-A model of knowledge development and increasing foreign market commitments. Journal of International Business Studies, 8(1): 23.

Khanna, T. \& Palepu, K. 1997. Why focused strategies may be wrong for emerging markets. Harvard Business Review, 75(4): 41-48.

Kostova, T. 1999. Transnational transfer of strategic organizational practices: A contextual perspective. Academy of Management Review, 24(2): 308-24.

Madhok, A. \& Keyhani, M. 2012. Acquisitions as entrepreneurship: Asymmetries, opportunities, and the internationalization of multinationals from emerging economies. Global Strategy Journal, 2(1): $26-40$.

Tan, J. \& Peng, M. W. 2003. Organizational slack and firm performance during economic transitions: Two studies from an emerging economy. Strategic Management Journal, 24(13): 1249-63.

Xu, D. \& Shenkar, O. 2002. Institutional distance and the multinational enterprise. Academy of Management Review, 27(4): 608-18.

Zaheer, S. 1995. Overcoming the liability of foreignness. Academy of Management Journal, 38(2): 341.

Zaheer, S., Schomaker, M. S., \& Nachum, L. 2012. Distance without direction: Restoring credibility to a much-loved construct. Journal of International Business Studies, 43(1): 18-27.

Hamid Akbari is an Assistant Professor of Strategic Management at the University of Ontario Institute of Technology. His research is mainly in the area of international strategy, with specific interest in emerging market firms. He has studied institutional environments of multinational corporations, performance determinants and outcomes of international acquisitions, and development of organizational capabilities. A paper based on his dissertation is a finalist for the Academy of Management GWU-CIBER Best Paper on Emerging Markets Award. 